\author{
R. Rogatynskyi ${ }^{1}$, R. Hevko ${ }^{1}$, Y. Nykerui ${ }^{1}$, O. Dmytriv $^{1}$, R. Rozum ${ }^{2}$ \\ ${ }^{1}$ Ivan Puluj Ternopil National Technical University, Ukraine; \\ ${ }^{2}$ Ternopil National Economical University, Ukraine \\ (E-mail: r_hevko@ukr.net)
}

\title{
The dynamic simulation model of apples contact interaction
}

\begin{abstract}
The mathematical model of apples shock interaction with each other and with working surfaces of technological equipment during their gathering, transportation and technological processing has been presented. In the model using the Hertz theory, strain and other running parameters of bodies shock interaction have been determined. To set changes to these parameters in time has been a peculiarity of the model, which allows simulate the process in the mode of the calculated experiment. The graphic change dependences of time contact forces, as well as examples of apples kinematics changes at initial angular and tangential velocities have been given.
\end{abstract}

Keywords: shock, contact interaction, apple, Hertz contact strain, mathematical model, calculated experiment, recovery coefficient.

\section{Introduction}

One of the most important requirements for apples is to ensure a long shelf life without losing conditional qualities. For this purpose, during their harvesting and processing, damages and excessive shock loads must be avoided because that may violate the integrity and structure of apples pulp. Therefore, when preparing the apple handling process and designing the appropriate technological equipment, it is necessary to follow the requirements that will ensure safe modes of harvesting, transportation and processing of apples for storage. According to the results of well-known researches [1-5] and everyday practical experience, depending on the varieties of apples, they have different dimensional, physical and technical characteristics. Since, as a rule, apples of smaller sizes are used mainly for the manufacture of juices, then in storage are laid mainly apples of larger sizes with a diameter of $60-80 \mathrm{~mm}$. Such apples, due to their greater weight, receive greater dynamic damage during transportation. In the shock theory, the assumption of fruits momentary impact, where the main parameters of interaction correspond to the law of saving the amount of movement, have been assumed. This assumption leads to a significant simplification of the interaction calculation model and it is inadmissible for the simulation of objects interaction in time and the simultaneous interaction of several fruits, their movement in the flow (container), etc., where the assumption of the momentality of the contact is meaningless. In studies [6-17], it has been shown that with a small impact load for simulation of shock interaction one can use a rheological model of an elastic body, and to determine the force of impact - the Hertz formula. However, the Hertz formula makes it impossible to establish the time for elastic contact of bodies and changes in contact forces, magnitude, and speed of convergence over time. Also, kinematics of bodies, mainly apples, at the time of and after contact, when they have initial angular or tangential velocities, have not been investigated.

\section{Material and method}

Long-term storage of apples is ensured by following high requirements that prevent their damage, that is, not exceeding the allowable contact strain when they interact with the technological surfaces and with each other. One of the most suitable ways of solving problems of apples contact interaction with each other and working surfaces is to construct a model based on the elastic contact interaction of apples on impact. This model has a real physical content at low kinetic energies of fruits. According to Hertz contact problem, the connection between the force of contact interaction $P_{12}$, the radius of the contact platform $a_{12}$, and the magnitude of the close convergence of the spheres (apples) $u_{12}$ are as follows $[5,7,8,10]$ :

$$
a_{12}=\sqrt[3]{\frac{3 \pi P_{12}\left(q_{1}+q_{2}\right) R_{1} R_{2}}{4\left(R_{1}+R_{2}\right)}} ; \quad u_{12}=\sqrt[3]{\frac{9 \pi^{2} P_{12}^{2}\left(q_{1}+q_{2}\right)^{2}\left(R_{1}+R_{2}\right)}{16 R_{1} R_{2}}},
$$


where $R_{1}$ and $R_{2}$ - radii of the spheres, $q_{1}$ and $q_{2}$ - constants characterizing elastic properties of interaction bodies and are determined through the Lame constants $\lambda_{i}$ and $\mu_{i}$, or, relayively, Poisson coefficients $\nu_{i}$ and shear modules $\mu_{i}=G_{i}$ and Jung (elasticity) $E_{i}$.

$$
q_{i}=\frac{\lambda_{i}+2 \mu_{i}}{4 \pi \mu_{i}\left(\lambda_{i}+\mu_{i}\right)} ; \quad \lambda_{i}=\frac{2 \nu_{i} G_{i}}{1-2 \nu_{i}} ; \quad \mu_{i}=G_{i}=\frac{E_{i}}{2\left(1+\nu_{i}\right)} .
$$

In accordance, the force of contact interaction $P_{12}$ of apples between each other or apple with platform of magnitude of hard convergence $u_{12}$ connected by dependence

$$
P_{12}=\frac{k_{12} u_{12}^{3 / 2}}{\sqrt{K_{1}+K_{2}}}
$$

where $k_{12}$ - a parameter that takes into account the elastic properties of the contact body in the Hertz contact problem; $K_{1}$ and $K_{2}$ - the average curvature of the surfaces of the interaction bodies at the point of contact (for curved surfaces with a minus sign). For an apple in the form of a sphere in radius $R_{i}$ average curvature of the surface (the sphere) $K_{i}=R_{i}$, in case of an apple impact with a flat platform, the average curvature of such is $K_{j}=0$.

The model parameter of two bodies interaction $k_{12}$ takes into account the mechanical properties of the interaction bodies,

$$
k_{12}=\frac{4}{3 \pi} /\left(\frac{1-\mu_{2}^{2}}{E_{2}}+\frac{1-\mu_{1}^{2}}{E_{1}}\right) .
$$

Consider the impact interaction of apples with spherical form radius $R_{1}$ with a hard flat platform. Implicit in the Cartesian coordinate system $O x y z$ apple platform surface, the center of its gravity has running coordinates $C\left[x_{0}(t) ; y_{0}(t) ; z_{0}(t)\right]$, is described by the dependence [11],

$$
f_{S}(x, y, x, t)=\left[\left(x-x_{0}(t)\right)^{2}+\left(y-y_{0}(t)\right)^{2}+\left(z-z_{0}(t)\right)^{2}-R_{1}^{2}\right]^{0,5}=0 .
$$

The potential of a geometric field, which is described by a function (5) at an arbitrary point $A\left(x_{A} ; y_{A} ; z_{A}\right)$ will be equal to the distance to the surface of the fruit (p. $E)$ at time $t, p_{A}=f_{S}\left(x_{A}, y_{A}, z_{A}, t\right)=l_{A E}(t)$.

Accordingly, the surface of the platform describe the normal plane equation that describes a similar field. For the case of a stationary platform

$$
f_{P}(x, y, x,)=\cos \alpha \cdot x+\cos \beta \cdot y+\cos \gamma \cdot z-d=0
$$

where $\alpha, \beta$, and $\gamma$ - directional angles of the platform normali vector; $d$ - the distance from the platform to the coordinates beginning.

At the point of contact of the apple with the plane $E\left(x_{E} ; y_{E} ; z_{E}\right)$ both functions (5) and (6) takes the value $f_{S}\left(x_{E}, y_{E}, z_{E}, t\right)=f_{P}\left(x_{E}, y_{E}, z_{E}\right)=0$, but normali to the surface of the apple $\bar{n}_{S}$ and sufaces of the platform $\bar{n}_{P}$ will be $\bar{n}_{S}=-\bar{n}_{P}$.

Here $\bar{n}_{S}=\operatorname{gradf}_{S} ; \bar{n}_{P}=\operatorname{gradf}_{P}=\cos \alpha \cdot \bar{i}+\cos \beta \cdot \bar{j}+\cos \gamma \cdot \bar{k}$.

So, the force vector of impact interaction $\bar{N}_{P}$, which influences on an apple from the side of the platform will be $\bar{N}_{P}=-\bar{P}_{21}=P_{21} \cdot \bar{n}_{P}$.

The apple movement speed at any given time $t$ will be determined by the vector

$$
\vec{\nu}_{S}(t)=\frac{\partial x_{0}(t)}{\partial t} \cdot \bar{i}+\frac{\partial y_{0}(t)}{\partial t} \cdot \bar{j}+\frac{\partial z_{0}(t)}{\partial t} \cdot \bar{k} .
$$

The value of the hard convergence of an apple by radius $R_{1}$ with platform, which is described by the dependence (5), at the point of contact will be

$$
u_{12}(t)=R_{1}-f_{P l}\left(x_{0}, y_{0}, x_{0},\right)=R_{1}-d+\cos \alpha \cdot x_{0}+\cos \beta \cdot y_{0}+\cos \gamma \cdot z_{0}=0 .
$$

In general case $i$ is such apple by weight $m_{i}$ can contact with other apples or work surfaces and have $j$ contact points $E_{i j}$. On the selected movable $i$ apple in general influence such forces as: earthly gravity $\bar{G}_{i}$; inertia $-m_{i} \bar{a}_{i}$, directed opposite to the acceleration vector $\bar{a}_{i}=d \bar{\nu}_{S} / d t$; normal and tangential forces $\bar{P}_{i j}$ and $\bar{F}_{i j}$ in each $E_{i j}$ - contact zone from interaction with $j$ body. Accordingly, moments also influence into an apple $\bar{M}_{P i j}$ and $\bar{M}_{F i j}$ from forces $\bar{P}_{i j}$ and $\bar{F}_{i j}$, the moments of twisting from the rotating motion of the fruit at the 
point of contact $\bar{T}_{i j}$ and inertial moments of forces. At the same time, equation of equilibrium of all forces, applied to the apple it is expedient to put in a fixed, basic coordinate system $O x y z$, and equation of equilibrium of forces moments - in its own coordinate system of the apple, $O^{\wedge} x^{\wedge} y^{\wedge} z^{\wedge}$ the center of which $O^{\wedge}$ located in the center of the apple $C\left[x_{0}(t) ; y_{0}(t) ; z_{0}(t)\right]$, and the axes are tightly bound with the body of the apple [6-8, 11]

$$
\sum_{j=1}^{k}\left(\bar{P}_{i j}+\bar{F}_{i j}\right)-m_{i} \bar{a}_{i}+\bar{G}_{i}=0 ; \quad \sum_{j=1}^{k}\left[\left(\bar{r}_{i j}^{\wedge}+\bar{\delta}_{i j}^{\wedge}\right) \times\left(\bar{P}_{i j}^{\wedge}+\bar{F}_{i j}^{\wedge}\right)+\sum_{j=1}^{k} T_{i j}^{\wedge}-\bar{L}_{o i}^{(e)}=0,\right.
$$

where $\bar{P}_{i j}$ and $\bar{P}_{i j}^{\wedge}$ - vectors of normal forces of elastic interaction on the Hertz model are given in the general and proper coordinate systems; $\bar{F}_{i j}$ and $\bar{F}_{i j}^{\wedge}$ - the corresponding vectors of tangential forces; $\bar{r}_{i j}$ and $\bar{r}_{i j}^{\wedge}-$ the corresponding radii-vectors of $i j$ zone; $\bar{\delta}_{i j}^{\wedge}=\bar{F}_{i j} \nu_{i} /\left(4 a_{i j} G_{i}\right)$ - the tangential displacement of contact platform from force $\bar{F}_{i j}^{\wedge}$, [ 6,7]; $\bar{L}_{o i}^{(e)}$-vector amount of forces moments.

In the coordinate system of a moving body $\bar{L}_{0 i}^{(e)}=\frac{d \bar{K}_{0 i}^{\wedge}}{d t}+\left(\left[\bar{\omega}_{0}^{\wedge} \times \bar{K}_{0 i}^{\wedge}\right]\right)$, where $\bar{K}_{0 i}^{\wedge}$ - apple kinetic moment. The twisting moments form a small fate of power factors, that act on a particle (less than 2-3\%), that's why they are not taken into account in the simplified model. Friction forces have been determined by AmontonCoulomb law $\bar{F}_{i j}=\mu \Delta \bar{\nu}_{e i j}^{\wedge} /\left|\Delta \bar{\nu}_{e i j}^{\wedge}\right|$, where $\mu$ - the coefficient of dry friction, $\bar{\nu}_{e i j}^{\wedge}-$ speed of the point on the apple surface relative to the platform $E_{i j}$ in contact zone.

The transition from the coordinate system $O x y z$ to $O^{\wedge} x^{\wedge} y^{\wedge} z^{\wedge}$ have been conducted in a homogeneous base $\zeta_{x} \zeta_{y} \zeta_{z} \zeta$ and own apple $\zeta_{x}^{\wedge} \zeta_{y}^{\wedge} \zeta_{z}^{\wedge} \zeta$ coordinate systems, where $\zeta=\zeta^{\wedge}-$ a scale multiplier [11, 12]. For the objects of unchanging volume $\zeta=\zeta^{\wedge}=1$. The relation between coordinate systems $O x y z$ and $O^{\wedge} x^{\wedge} y^{\wedge} z^{\wedge}$ with homogeneous coordinates will be the following

$$
x=\zeta_{x} / \zeta ; \quad y=\zeta_{y} / \zeta ; \quad z=\zeta_{z} / \zeta ; \quad x^{\wedge}=\zeta_{x}^{\wedge} / \zeta^{\wedge} ; \quad y^{\wedge}=\zeta_{y}^{\wedge} / \zeta^{\wedge} ; \quad z^{\wedge}=\zeta_{z}^{\wedge} / \zeta^{\wedge}
$$

The matrix record of the transition from its own coordinate system of the apple to the base will look like [12]:

$$
M(R)=\left|\begin{array}{cccc}
\alpha_{11} & \alpha_{12} & \alpha_{13} & x_{0}(t) \\
\alpha_{21} & \alpha_{22} & \alpha_{23} & y_{0}(t) \\
\alpha_{31} & \alpha_{32} & \alpha_{33} & z_{0}(t) \\
0 & 0 & 0 & 1
\end{array}\right| M\left(R^{\wedge}\right)=\Pi_{\nu} \Pi_{\omega}(\alpha) M\left(R^{\wedge}\right)
$$

where $\alpha_{i j}$ - guiding cosines between the axes of the base and their own coordinate systems; $M(R)=|x y z 1|^{T}-$ a matrix that specifies the coordinates of an arbitrary point of the body in the general coordinate system $O x y z$ and corresponds to the vector $r(t)=x(t) i+y(t) j+z(t) k ; M\left(R^{\wedge}\right)=\left|x^{\wedge} y^{\wedge} z^{\wedge} 1\right|^{T}-$ matrix corresponding to the vector $r(t)=x^{\wedge}(t) i+y^{\wedge}(t) j+z^{\wedge}(t) k$ and specifies the coordinates of the same point in its own coordinate system of the object $O^{\wedge} x^{\wedge} y^{\wedge} z^{\wedge} ; r_{0}(t)=x_{0}(t) i+y_{0}(t) j+z_{0}(t) k$ - radius vector that connects the beginning of the base coordinate system with the start of its own aperture coordinate system, which coincides with its gravity center; $\Pi_{\nu}$ and $\Pi_{\omega}-$ matrices of linear displacements and turns of its own coordinate system $O^{\wedge} x^{\wedge} y^{\wedge} z^{\wedge}$ in general Oxyz:

Similarly, the matrices of the inverse transform from the inertial coordinate system to the own coordinate system of the object jave been written.

In an expanded form, the system of equations (9) takes the form:

$$
\begin{gathered}
\sum_{i=1}^{k} P_{i j}\left[\operatorname{grad}\left(f_{i}\right)-\frac{\mu \Delta \bar{\nu}_{e i j}}{\left|\Delta \bar{\nu}_{e i j}\right|}\right]-m_{i} \bar{a}_{i}+\bar{G}_{i}=0 ; \\
\sum_{i=1}^{m} P_{i j}\left\{\left(\bar{r}_{i j}^{\wedge}+\bar{\delta}_{i j}^{\wedge}\right) \times\left[\operatorname{grad}\left(f_{i}^{\wedge}\right)-\frac{\mu \Delta \bar{\nu}_{e i j}^{\wedge}}{\left|\Delta \bar{\nu}_{e i j}^{\wedge}\right|}\right]\right\}-\bar{L}_{0 i}^{(e)}=0 .
\end{gathered}
$$

Here the first equation of the system (11) is written in the base (fixed) coordinate system, and the second - in the own (moving) coordinate system of the apple.

The indicated dependences are the basis for constructing an imitation model for the interaction of apples with each other and with technological surfaces. In the model, the description of bodies interaction has been given by the normal equations of their surfaces, whose potential geometric fields determined their mutual placement in space, their convergence and availability of contact points. In case of contact, the interval $\Delta t$ was set for the 
procedure of numerical differentiation. Step by step the amount of hard convergence $u_{12}$ and contact forces $\bar{P}_{i j}$ and $\bar{F}_{i j}$, that occur at such convergence and moments from these forces have been determined. The next step was to determine the linear and angular accelerations from the forces found and the new values of the velocities and displacements of each body (apple) interaction and their linear and angular velocities, which defined new coordinates of the bodies through the period of time $\Delta t$ and new levels of hard convergence $u_{i j}$ and contact forces $\bar{P}_{i j}$ and $\bar{F}_{i j}$.

In order to take into account energy losses in determining the contact interaction forces, equation (3) was represented as $[6,7]$

$$
P_{12}=\frac{k_{12} u_{12}^{3 / 2}\left[1+k_{e}+\left(1-k_{e}\right) t h\left(-\lambda d u_{i j} / d t\right)\right]}{2 \sqrt{K_{1}+K_{2}}},
$$

where $k_{e}$ - coefficient, which depends on the coefficient of recovery at impact, $k_{e}=0.8-0.95 ; \lambda-$ parameter of the model smoothing the load curve at the point of maximum force value $P_{12}, \lambda>10$; Parameters of the model $k_{e}$ and $\lambda$ are specified experimentally from the condition while providing a given recovery factor $e$.

\section{Results}

The constructed model allowed to conduct a computational experiment and set the time for contact interaction $t_{k}$ and running forces of contact interaction, depending on the physical and mechanical characteristics of the interaction bodies, as well as kinematics of bodies (apples) during contact interaction, depending on the initial conditions.

The study of the shock interaction of one apple with a hard platform has a significant practical value, because it is one of the most common case of fruits bruising. Implementation of the models for different initial conditions is presented in Figure 1-5.

In particular, in Figure 1 it has been shown a graph of time variation of shock contact interaction $P=P_{12}$ for an apple with a diameter of $80 \mathrm{~mm}$, the modulus shift of which is $\mu_{1}=G_{1}=1.1 \mathrm{MPa}$, Poisson's coefficient $\nu_{1}=0.18$ with a rigid steel surface $\left(G_{2}=8.1 \times 10^{10} \mathrm{~Pa}, \nu_{2}=0.28\right)$ for cases where the initial apple speed at the moment of contact varies from $\nu_{0}=0.2 \mathrm{~m} / \mathrm{s}$ till $\nu_{0}=1.4 \mathrm{~m} / \mathrm{s}$. In this case, the force of interaction increased from $P_{0.2}=11.5 \mathrm{~N}$ at the time of interaction $t_{0.2}=0.0088 \mathrm{~s}$, till $97.0 \mathrm{~N}$ at $t_{1.4}=0.0055 \mathrm{~s}$.

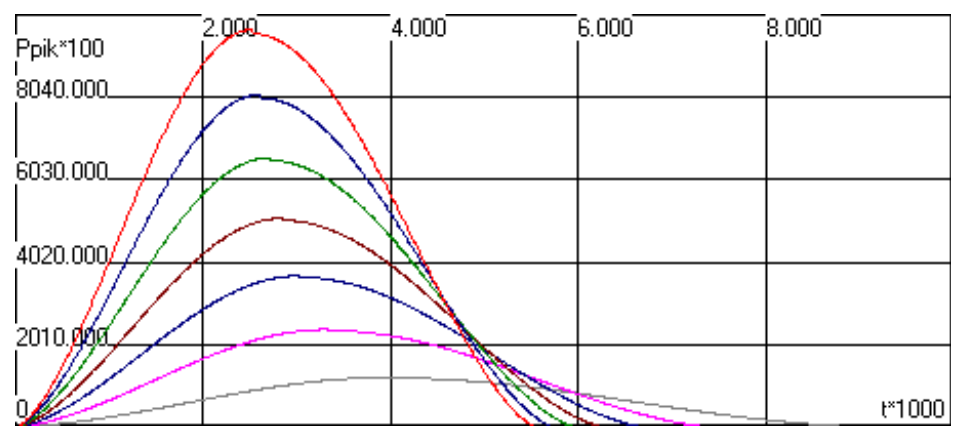

Figure 1. The change of the running force of the apple interaction contact $\left(G_{1}=1 \mathrm{MPa}, \nu_{1}=0.18\right)$ with steel platform $\left(G_{2}=8.1 \times 10^{10} \mathrm{~Pa}, \nu_{2}=0.28\right)$ at different initial velocities of interaction

$$
\nu_{0} \in[0.2 ; 0.4 ; 0.6 ; 0.8 ; 1.0 ; 1.2 ; 1.4 ;] \mathrm{m} / \mathrm{s}
$$

From the graph, it is clear that with the increase of the initial rate of contact, the force of impact interaction significantly increases with a slight decrease in contact interaction time.

Figure 2 shows a graph of changes in the time of the force of impact contact interaction $P=P_{12}$ for an apple of the same physical and mechanical characteristics for different diameters $(6 ; 8$ and $10 \mathrm{~mm})$ with a steel platform at initial contact speeds $\nu_{0}=0.5 \mathrm{~m} / \mathrm{s}$ (bottom graph) and $\nu_{0}=1.0 \mathrm{~m} / \mathrm{s}$.

The analysis of Figure 2 shows that with increased apple size, the force and time of the contact interaction increases, and at the lower collision rates, the interaction time is greater. Figure 3 shows the graphical dependences of the time variation of the impact contact interaction force 12 with a steel platform for apples of different hardness, that is, different values of the displacement module, at the initial collision speed $\nu_{0}=1.0 \mathrm{~m} / \mathrm{s}$. 
The dynamic simulation model...

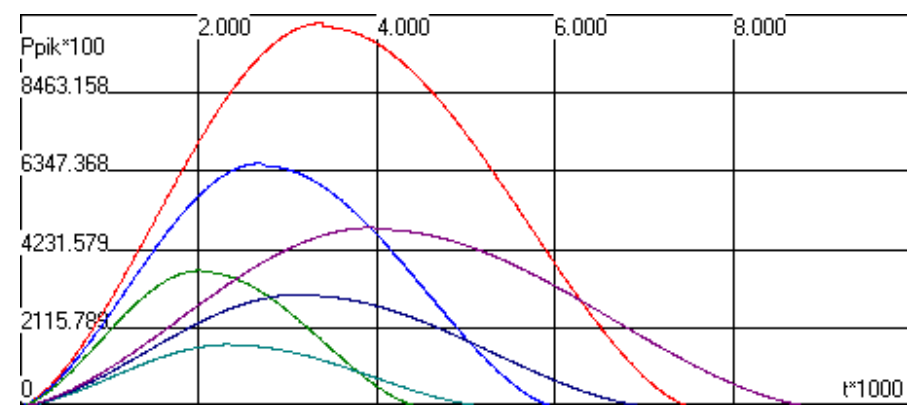

Figure 2. The change of the running force of the apple interaction contact

$\left(D=80 \mathrm{~mm}, \nu_{1}=0.18\right)$ with different diameters $D \in[60 ; 80 ; 100] \mathrm{mm}$ with a steel platform

$\left(G_{2}=8.1 \times 10^{10} \mathrm{~Pa}, \nu_{2}=0.28\right)$ at interaction speed $\nu_{0}=0.5 \mathrm{~m} / \mathrm{s}$ and $\nu_{0}=1.0 \mathrm{~m} / \mathrm{s}$

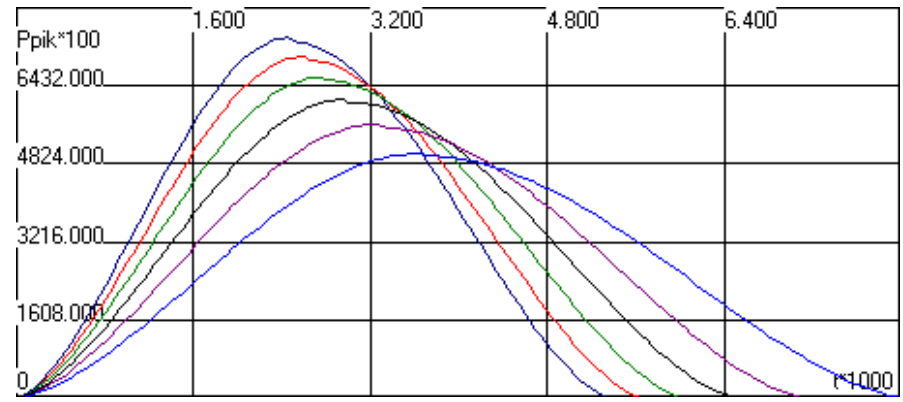

Figure 3. The change of the running force of the apple interaction contact at

$\left(D=80 \mathrm{~mm}, \nu_{1}=0.18\right)$ of different hardness $G_{1} \in[0.6 ; 0.8 ; 1.0 ; 1.2 ; 1.4 ; 1.6] \mathrm{MPa}$ with a steel platform $\left(G_{2}=8.1 \times 10^{10} P a, \nu_{2}=0.28\right)$ at a speed collision $\nu_{0}=1.0 \mathrm{~m} / \mathrm{s}$

From the graphs it has been seen that for harder apples, the impact forces are larger with less contact time interaction.

Figure 4 shows the interaction of apples with platforms of different materials.

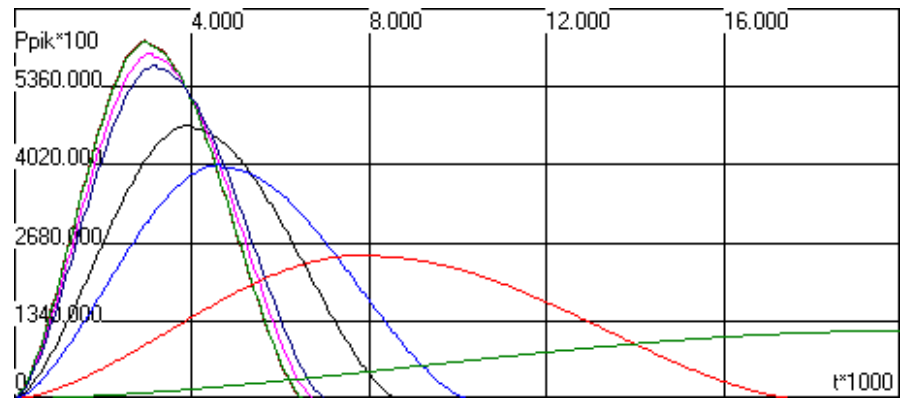

Figure 4. The change of the running force of the apple interaction contact

$\left(D=80 \mathrm{~mm}, G_{1}=1 \mathrm{MPa}, \nu_{1}=0.18\right)$ with an platform with different values of the shift modulus

$$
G_{2} \in\left[1 \cdot 10^{4} ; 1 \cdot 10^{5} ; 5 \cdot 10^{5} ; 1 \cdot 10^{6} ; 5 \cdot 10^{6} ; 1 \cdot 10^{7} ; 1 \cdot 10^{8}\right]
$$

It follows from the graphs (Fig. 4) that the impact strength can be significantly reduced only when the platform is made of a material for which the shift modulus (or the Young module) is smaller or at least equal to the apple displacement modulus. The shiftness platform change in the rate $G_{2}>1 \cdot 10^{8}$ practically does not affect on the change in the force of impact $P_{12}$. So, the replacement of the steel platform on the wooden $\left(G_{2}=4 \cdot 10^{9} \mathrm{~Pa}\right)$ practically does not reduce the forces of contact interaction.

In the case of falling packets with apples placed in several layers into the platform, the most injured are apples placed in the lower layer, which are in contact with the rigid bottom and perceive loading from the upper layers. 
Figure 5 shows graphs of force time variation of apples contact interaction in the presence of upper layers.

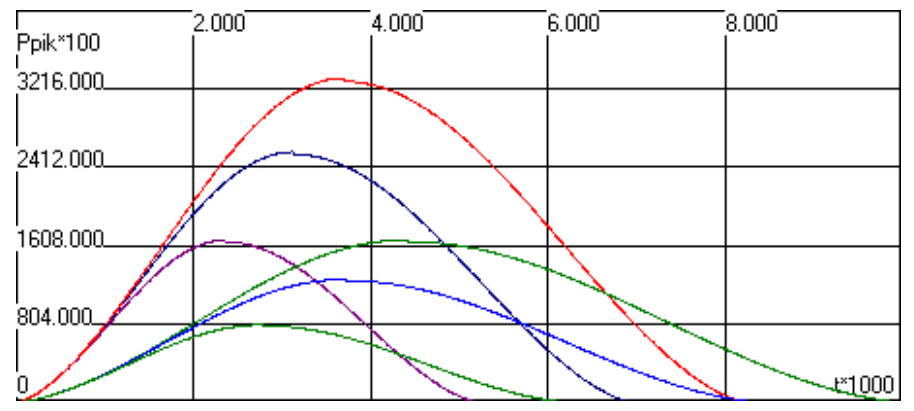

Figure 5. The change of the running force of the lower layers the apple interaction contact $\left(D=80 \mathrm{~mm}, G_{1}=1 M P a, \nu_{1}=0.18\right)$ in a container with a plastic platform $\left(G_{2}=1 \times 10^{9} \mathrm{~Pa}, \nu_{2}=0.3\right)$ with the placement of apples in 1,2 and 3 layers with the speed of interaction with the container to the platform $\nu_{0}=0.25 \mathrm{~m} / \mathrm{s}$ and $\nu_{0}=0.5 \mathrm{~m} / \mathrm{s}$

The approximation of dependencies of force impact change in time for a case of contact interaction with sufficient accuracy for practical use, it is advisable to make dependencies of the

$$
P_{i j}(t)=P_{i j \max }\left(\frac{t}{\tau \cdot t_{k}}\right)^{\varepsilon}\left[\frac{t_{k}-t}{t_{k}(1-\tau)}\right]^{\varepsilon(1-\tau) / \tau},
$$

where $\varepsilon$ - the shape coefficient of the curve, for elastic impact $\varepsilon \approx 2$, for visco-elastic and elastic-plastic bodies $\varepsilon<1.5 ; t_{k}$ - a time of contact interaction; $\tau$ - the asymmetry parameters of the curve interaction, $\tau=t_{P \max } / t_{k}$, for a symmetric curve $\tau=0.5$. The bigger values of the coefficient $\varepsilon$ are taken for greater speeds of collision and normal impact without a tangential component.

If the mass element $j$ significantly greater than mass element $i, m_{j}>m_{i}$ so, in accordance with the law of conservation of momentum, element with mass $m_{i}$ on impact it changes the magnitude and direction of movement (reflected from the surface of the platform) and therefore the ratio is the following

$$
m_{i} \nu_{0}(1+e)=\int_{0}^{t_{k}} P_{i j} d t=k_{P} P_{i j \max } t_{k}
$$

where $e$ - recovery coefficient at impact, for apples $e=0.25-0.35 ; k_{P}$ - the parameter determining the shape effect of the curve on the magnitude of the force impulse.

The shape of the curve varies a liitle bit from the physical and mechanical characteristics of the apple and to a small extent depends on the speed of impact. For critical speed of apples collision with a hard platform $k_{P}=0.53-0.54$.

Firthermore, taking into account (14) the dependence (13) takes the form

$$
P_{i j}(t)=\frac{m_{i} \nu_{0}(1+e)}{k_{P} t_{k}}\left(\frac{t}{\tau \cdot t_{k}}\right)^{\varepsilon}\left[\frac{t_{k}-t}{t_{k}(1-\tau)}\right]^{\varepsilon(1-\tau) / \tau} .
$$

Since dependence (15) describes the change in the force of contact interaction at a given contact time $t_{k}$, which is easy to install experimentally, so it has a significant practical value.

The developed model also allows to simulate a change in the kinematic parameters of apples when they are transported on technological surfaces, taking into account their initial linear and angular displacements. In Figure 6 and 7 the kinematics of the transition from slipping to rolling the apples on a steel platform at different initial values of linear and angular velocities (without impact) has been shown. 
The dynamic simulation model...

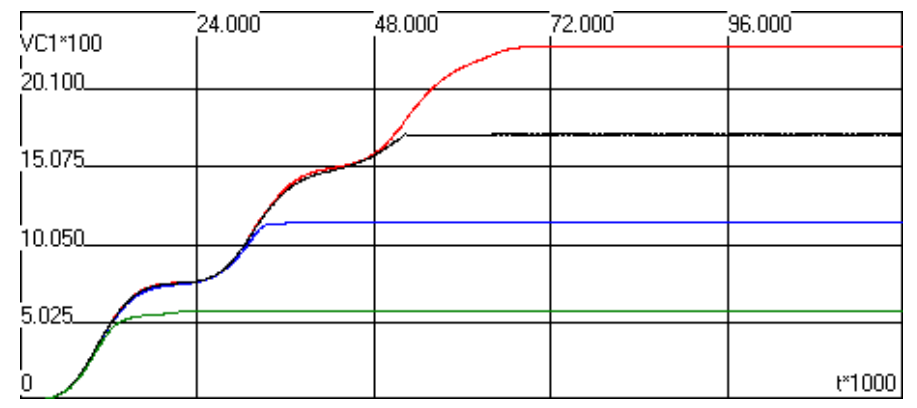

Figure 6 . The change of apples linear speed $\left(D=80 \mathrm{~mm}, G_{1}=1 M P a, \nu_{1}=0.18\right)$ on steelsurface $\left(G_{2}=8.1 \times 10^{10} \mathrm{~Pa}, \nu_{2}=0.28\right)$ in the transition from slipping to rolling at an initialspeed $\nu_{x}=0$ and different angular velocities $\omega_{y}=5 ; 10 ; 15 ; 20 \mathrm{~s}^{-1}$

\begin{tabular}{|l|l|l|l|l|}
\hline $1202 \times 100$ & & & & \\
1608.000 & & & & \\
\hline
\end{tabular}

Figure 7. The change of apples linear speed $\left(D=80 \mathrm{~mm}, G_{1}=1 M P a, \nu_{1}=0.18\right)$ on steel surface $\left(G_{2}=8.1 \times 10^{10} \mathrm{~Pa}, \nu_{2}=0.28\right)$ in the transition from slipping to rolling at an initial speed $\omega_{y}=0$ and different angular velocities $\nu_{x} \in 0.25 ; 0.5 ; 0.75 ; 1.0 \mathrm{~m} / \mathrm{s}$

As follows from the figures, the transition from slipping to rolling of apples having an initial only linear or angular velocity occurs over a short period of time (less than $0.1 s$ ).

\section{Conclusions}

The deduced dependencies are the basis of the simulation mathematical model, which allows to determine not only the parameters of contact interaction of apples between themselves or with technological surfaces, but also to simulate in the mode of the computational experiment the processes of transportation of apples, their movement during processing under the conditions of interaction with several objects simultaneously. According to the results of the study, it was found that the contact time of the apples between themselves and in hard containers does not exceed $0.001 \mathrm{~s}$. It is grater for apples of larger size, of soft varieties and with layered apples placed in the container. To significantly reduce the force of contact interaction and increase the contact time (more than $0.01 \mathrm{~s}$ ), it is necessary that the modulus of the elasticity of the platform was one-two times less than the modulus of apples elasticity. With the increase in the collision rate of apples with the platform or among themselves, the contact interaction strength increases significantly with a slight decrease in contact time. The critical values of the force of the impact contact interaction, in which the structure of the flesh of the apples for the solid varieties has not disturbed, is $P_{\max }=80$, for soft $-35-40$.

\section{References}

1 Roudot A.-C.G. Modelling the Response of Apples to Loads / A.-C.G. Roudot, F. Duprat, C. Wenian // Journal of Agricultural Engineering Research. - 1991. - 48(4). - 2497259.

2 Степанова Е.Г. Реологические свойства яблок при различных свойствах их обработки / Е.Г. Степанова, В.А. Причко // Известия вузов. Пищевая технология. - 1999 . - №5 - 6. - С.72.

3 Yuwana Y. Prediction of Apple Bruising Based on the Instantaneous Impact Shear Stress and Energy Absorbed / Y. Yuwana, F. Duprat // International Agrophysics. - 1998. - 12. - 1337140. 
4 Rybczynski R. Mechanical. Resistance of Apple in Different Place of Fruit. / R. Rybczynski, B. Dobrzanski // International Agrophysics. - 1994. - 9(3). - 4557459.

5 Grotte M. Young's modulus, poisson's ratio, and lame's coefficients of golden delicious apple. / M. Grotte, F. Duprat, E. Piétri \& D. Loonis // International Journal of Food Properties. - 2002. - 5(2). - P. 333349. DOI: $10.1081 /$ JFP-120005789.

6 Рогатинский Р.М. Силовое взаимодействие коренебульбоплодив с рабочими органами шнековых очистителей / Р.М. Рогатинский // Вестн. Нац. аграр. ун-та. - М.: НАУ, 1997. - Т. 1. - С. 98-103.

7 Рогатинский Р.М. Модель контактного взаимодействия частицы груза с рабочими поверхностями сельскохозяйственных машин / Р.М. Рогатинский и др. // Вестн. Харьков. гос. техн. ун-та сельского хозяйства «Механизация сельскохозяйственного производства». - Харьков, 2003. - Вип. 21. C. $222-228$.

8 Гупка Б.В. Модели контактного взаимодействия частиц технологической среды с рабочими поверхностями деталей машин / Б.В. Гупка, А.Р. Рогатинская // Науч. заметки: межвуз. сб. (по направлению «Инженерная механика»). - Вып. 11. - Луцк: Изд-во ЛГТУ, 2002. - С. 114-120.

9 Пик А.И. Динамическая модель взаимодействия частиц сыпучего груза между собой и с рабочими поверхностями машин / А.И. Пик, А.В. Дудин, А.Р. Рогатинская // Вестн. Харьков. гос. техн. ун-та сельского хозяйства. Механизация сельскохозяйственного производства. - Харьков, 2004. - Вып. 24. - C. $120-127$.

10 Hanaor D.A.H. Contact mechanics of fractal surfaces by spline assisted discretisation / D.A.H. Hanaor, Y. Gan, I. Einav // International Journal of Solids and Structures. -2015. - 59. - P. 121-131. DOI:10. 1016/j.ijsolstr.2015.01.021.

11 Рогатинський Р.М. Моделювання процесів взаємодії шнекових робочих органів із коренебульбоплодами / Р.М. Рогатинський // Вісник Національного аграрного університету. - Киев: НАУ, 1997. T. $1 .-$ C. $103-108$.

12 Шенен П. Математика и САПР: [В 2-х кн.] Кн. 1. / П. Шенен, М. Коснар, И. Гардан и. др.; пер. с фр. - М.: Мир, 1988. - 204 с.

13 Гевко Р.Б. Направления совершенствования свеклоуборочной техники сникив / Р.Б. Гевко, И.Г. Ткаченко, С.В. Синий, В.М. Булгаков, Р.М. Рогатинский, О.Б. Павелчак. - Луцк: ЛГТУ, 1999. - 168 с.

14 Hevko R.B. Determination of interaction parameters and grain material flow motion on screw conveyor elastic section surface / R.B. Hevko, S.Z. Zalutskyi, Y.B. Hladyo, I.G. Tkachenko, O.L. Lyashuk, O.M. Pavlova, B.V. Pohrishchuk, O.M. Trokhaniak, N.V. Dobizha // INMATEH: Agricultural engineering. Bucharest, Romania. - 2019. - Vol. 57. - No. 1. - P. 123-134.

15 Hevko R.B. The influence of bluk material flow on technical and economical performance of a screw conveyor / R.B. Hevko, V.M. Baranovsky, O.L. Lyashuk, B.V. Pohrishchuk, Y.P. Gumeniuk, O.M. Klendii, N.V. Dobizha // INMATEH: Agricultural engineering. Bucharest, Romania. - 2018. - Vol. 56. - No. 3. - P. $175-184$.

16 Lyashuk O.L. Modelling of the vertical screw conveyer loading / O.L. Lyashuk, O.R. Rogatynska, D.L. Serilko // INMATEH: Agricultural engineering. Bucharest, Romania. - 2015. - Vol. 45. - No. 1. - P. 87-94.

17 Lyashuk O.L. Mathematical model of bending vibrations of a horizontal feeder-mixer along the flow of grain mixture / O.L. Lyashuk, M.B. Sokil, V.M. Klendiy, O.P. Skyba, O.L. Tretiakov, L.M. Slobodian et al. // INMATEH: Agricultural engineering. Bucharest, Romania. - 2018. - Vol. 55. - No. 2. - P. 35-44.

\author{
Р.Рогатынский, Р.Гевко, Ю.Никеруй, О.Дмитров, Р.Розум
}

\title{
Алманың өзара жанасуы әрекетінің динамикалық имитациялық моделі
}

\begin{abstract}
Алмалардың бір-бірімен, сондай-ақ технологиялық жабдықтардың жұмыс беттерімен оларды жинау, тасымалдау және технологиялық өңдеу кезіндегі соққымен өзара әсерлесуінің математикалық моделі ұсынылған. Герц теориясын пайдалана отырып модельде кернеуді, сондай-ақ дененің соққылық
\end{abstract}


әсерінің басқа да ағымдағы параметрлерін анықтайды. Модельдің ерекшелігі уақыт параметрлерінің өзгеруін орнату болып табылады, бұл есептелген эксперимент режимінде процесті модельдеуге мүмкіндік береді. Сонымен қатар, бастапқы бұрыштық және тангенциялық жылдамдық кезіндегі алма кинематикасының өзгеру мысалдары келтірілген.

Kiлm сөздер: соққы, өзара байланысу әрекеті, алма, Герцтің түйіспелі кернеуі, математикалық модель, есептелетін эксперимент, қалпына келтіру коэффициенті.

\author{
Р.Рогатынский, Р.Гевко, Ю.Никеруй, О.Дмитров, Р.Розум
}

\title{
Динамическая имитационная модель контактного взаимодействия яблок
}

\begin{abstract}
Представлена математическая модель ударного взаимодействия яблок между собой, а также с рабочими поверхностями технологического оборудования при их уборке, транспортировке и технологической обработке. В модели с использованием теории Герца определяются напряжения, а также другие текущие параметры ударного взаимодействия тел. Особенность модели есть установление изменений параметров во времени, что позволяет моделировать процесс в режиме исчисляемого эксперимента. Приведены графические зависимости изменения контактных сил во времени, а также примеры изменения кинематики яблок при начальных угловых и тангенциальных скоростях.
\end{abstract}

Ключевые слова: удар, контактное взаимодействие, яблоко, контактные напряжения Герца, математическая модель, исчисляемый эксперимент, коэффициент восстановления.

\section{References}

1 Roudot, A.-C.G., Duprat, F., \& Wenian, C. (1991). Modelling the Response of Apples to Loads. Journal of Agricultural Engineering Research, 48 (4), 2497259.

2 Stepanova, E.G., \& Prichko, V.A. (1999). Reolohicheskie svoistva yablok pri razlichnyikh svoistvakh ikh obrabotki [The rheological properties of apples with different properties of their processing]. Izvestiia vuzov. Pischevaia tehnolohiia - Izvestiia vuzov. Food technology, No. 5-6, 72 [in Russian].

3 Yuwana, Y., \& Duprat, F. (1998). Prediction of Apple Bruising Based on the Instantaneous Impact Shear Stress and Energy Absorbed. International Agrophysics, 12, 1337140.

4 Rybczynski, R., \& Dobrzanski, B. (1994). Mechanical. Resistance of Apple in Different Place of Fruit. International Agrophysics, 9 (3), 4557459.

5 Grotte, M., Duprat, F., Piétri, E., \& Loonis, D. (2002). Young's modulus, poisson's ratio, and lame's coefficients of golden delicious apple. International Journal of Food Properties, 5:2, 333-349, DOI: 10.1081 /JFP-120005789.

6 Rohatynskyi, R.M. (1997). Sylova vzaiemodiia korenebulboplodiv iz robochymy orhanamy shnekovykh ochysnykiv [The power interaction of root crops with working organs of screw cleaners]. Visnyk Natsionalnoho ahrarnoho universiteta - Bulletin of the National Agrarian University, Vol. 1, 98-103. Kyiv: NAU [in Ukrainian].

7 Rohatynskyi, R.M., \& et al. (2003). Model kontaktnoi vzaiemodii chastynky vantazhu z robochymy poverkhniamy silskohospodarskykh mashyn [Model of contact interaction of a particle with the working surfaces of agricultural machines]. Visnyk Kharkivskoho derzhavnoho tekhnichnoho universytetu silskoho hospodarstva «Mekhanizatsiia silskohospodarskoho vyrobnytstva» - Journal of the Kharkov State Technical University of Agriculture «Mechanization of agricultural production», Vol. 21, 222-228. Kharkiv, LSTU [in Ukrainian].

8 Hupka, B.V., \& Rohatynska, O.R. (2002). Modeli kontaktnoi vzaiemodii chastynok tekhnolohichnoho seredovyshcha z robochymy poverkhniamy detalei mashyn [Models of contact interaction of technological environment particles with working surfaces of machine parts]. Naukovi notatky. Mizhvuzivskyi zb. (za napriamkom «Inzhenerna mekhanika») - Scientific notes. Interuniversity collection ( Engineering Mechanics»), Lutsk, LDTU. Vol. 11, 114-120 [in Ukrainian]. 
9 Pik, A.I., Dudin, O.V., \& Rohatynska, O.R. (2004). Dynamichna model vzaiemodii chastynok sypkoho vantazhu mizh soboiu ta z robochymy poverkhniamy mashyn [The dynamic model of interaction of bulk cargo particles with each other and with working surfaces of machines]. Visnyk Kharkivskoho derzhavnoho tekhnichnoho universytetu silskoho hospodarstva - Bulletin of Kharkiv State Technical University of Agriculture, Mechanization of agricultural production, Vol. 24, 120-127 [in Ukrainian].

10 Hanaor, D. A. H., Gan, Y., \& Einav, I. (2015). Contact mechanics of fractal surfaces by spline assisted discretisation International Journal of Solids and Structures. 59: 121-131. DOI:10.1016/j.ijsolstr.2015.01. 021.

11 Rohatynskyi, R.M. (1997). Modeliuvannia protsesiv vzaiemodii shnekovykh robochykh orhaniv iz korenebulboplodamy [Modeling of the processes of interaction of screw working bodies with root tubes]. Visnyk Natsionalnoho ahrarnoho universytetu - Bulletin of the National Agrarian University, Kyiv, NAU. Vol. X1, 103-108. [in Ukrainian].

12 Shenen, P., Kosnar, M., \& Gardan, I., et al. (1988). Matematika i SAPR: V dvuh kn. Kn. 1.Per. s frants. [Mathematics and CAD: In two books. Book. 1.Transl from Franch]. Moscow: Mir [in Russia].

13 Hevko, R.B., Tkachenko, I.H., Synii, S.V., Bulhakov, V.M., Rohatynskyi, R.M., \& Pavelchak, O.B. (1999). Napriamky vdoskonalennia buriakozbyralnoi tekhniky snykiv [Directions of improvement of beet harvesting technique of cutters]. Lutsk: LDTU [in Ukrainian].

14 Hevko, R.B., Zalutskyi, S.Z., Hladyo, Y.B., Tkachenko, I.G., Lyashuk, O.L., Pavlova, O.M., Pohrishchuk, B.V., Trokhaniak, O.M., \& Dobizha, N.V. (2019). Determination of interaction parameters and grain material flow motion on screw conveyor elastic section surface. INMATEH: Agricultural engineering. Bucharest, Romania, Vol. 57, No. 1, 123-134.

15 Hevko, R.B., Baranovsky, V.M., Lyashuk, O.L., Pohrishchuk, B.V., Gumeniuk, Y.P., Klendii, O.M., \& Dobizha, N.V. (2018). The influence of bluk material flow on technical and economical performance of a screw conveyor. INMATEH: Agricultural engineering. Bucharest, Romania, Vol. 56, No. 3, $175-184$.

16 Lyashuk, O.L., Rogatynska, O.R., Serilko, D.L. (2015). Modelling of the vertical screw conveyer loading INMATEH Agricultural Engineering, Bucharest. Romania. Vol. 45, No. 1, 87-94,

17 Lyashuk, O.L., Sokil, M.B., Klendiy, V.M., Skyba, O.P., Tretiakov, O.L., Slobodian, L.M., \& Slobodian, N.O. (2018). Mathematical model of bending vibrations of a horizontal feeder-mixer along the flow of grain mixture, INMATEH Agricultural Engineering, Bucharest. Romania, Vol. 55, No. 2, 35-44. 